\title{
The Study on the Relationship between English Self-concept and Significant Others
}

\author{
Meihua Wang \\ Inner Mongolia University for the Nationalities, Tongliao, China
}

\begin{abstract}
This study investigate the role of significant others in shaping the academic self-concept of Chinese college students with a questionnaire research. The questionnaire research was implemented with thirty second-year college students of two classes. For each class, the questionnaires were administered in two sessions. They include a self-evaluation scale and an other-evaluation scale. The subjects evaluated themselves and at the same time were evaluated by the other four. Statistical analysis of the Questionnaire yields the finding that the inferred English self-concept (Others' perceptions) is highly correlated with the English self-concept. The finding suggests a chain of relationships between Pronunciation self-concept, others' perceptions and English self-concept. Implications are then discussed with the affective problem and language teaching and learning in SLA.
\end{abstract}

Index Terms - self-concept, academic self-concept, inferred self-concept, significant others

\section{INTRODUCTION}

Second language researchers generally agree that academic performance is not merely a cognitive activity. It may involve a tangled skein of variables, many of which could be non-cognitive, like cultures, society, learners' age, IQ, aptitude and personality. With this in mind, some researchers begin to look at non-cognitive factors for explanations of the mysteries of language and language learning. In recent years, there has been mounting research on the role of affective factors on language learning (Krashen, 1985; Gardner, 1985, 1993; Schumann, 1994, 1997; Stevick, 1976, 1980, 1986, 1990, 1998; Arnold, 1999). Among the intertwined and interrelated elements in the affective domain, self-concept, "that dynamic and motivating set of attitudes held about oneself" (Burns, 1979, p.83), is receiving more and more attention in education.

Based on the fact that "self-concept" is multidimensional and hierarchical, most of the contemporary work in this aspect has focused on the relationship between academic self-concept and academic performance, and has evoked the hot chicken-or-egg-first issue. Few researchers have inquired into what contribute to the formation of individual self-concept. Special attention is paid to the role of significant others in English language learning, but unfortunately rarely addressed in literature, let alone being empirically studied. The writer sets out to examine the formation of the English self-concept of Chinese learners by exploring the role of significant others in the construct of "self-concept".

The notion of "significant others" has been construed as part of the construct of "self-concept". However, even in the research history of psychology, few empirical studies have been conducted to investigate how significant others influence the formation of one's self-concept, not to mention second language learning.

In short, the issue of self-concept is important to language teaching and learning. English self-concept largely remains an uncharted land to explore. This article tends to examine one of the factors affecting the formation of English self-concept of Chinese learners, namely, significant others (English teachers and peers).

\section{LITERATURE REVIEW}

It is not until recently that the psychological construct of "self-concept" has been introduced into second language pedagogy. This change is in conformity with the current research interest in individual differences in second language acquisition, the contribution of the individual learner to the learning process (Williams \&Burden, 2000). Nevertheless, scant empirical research along this line has been reported in second language area.

\section{A. Self-concept}

The definition of self-concept varies widely with different theories of the self. Some viewed it basically as a cognitive construction - "a ratio of individual's successes to one's pretensions" (Keith \& Bracken, 1996, p. 91). Others focused more on the behavioral component of the self, like Bandura; still others, like Cooley (1902), Mead (1934), Baumeister (1990), emphasized the affective dimension of the self, relating it to others' evaluation and depressed affect. Besides, there are specially made definitions for a specific purpose of a single study.

Nevertheless, extensive data, especially factor-analytic studies, have revealed that a multifaceted model of self can better explain relative phenomena. In Shavelson et al's (1976) classic proposal of a multidimensional and hypothetical model of self-concept, they defined self-concept as "a person's self-perceptions formed through experience with and interpretations of his or her environment", which are "influenced especially by evaluations by significant others, 
reinforcements, and attributions for the individual's own behavior" (p. 413). This study, taking self-concept as an affective domain, could explicate better its role in language learning and teaching than a cognitive perspective for which the internal factors rather than the external ones in shaping one's self-concept being the focus.

\section{B. Academic Self-concept}

Global self-concept can be divided into non-academic (physical, social, emotional) and academic self-concepts, which can then split into even more specific components, like mathematics self-concept, English self-concept, and history self-concept. Strein (1993) claimed that the construct of academic self-concept bears two fundamental characteristics. First, it reflects descriptive (e.g., "I like English") as well as evaluative (e.g., I am good at English) aspects of self-perception. Second, it tends to "focus on scholastic competence, rather than attitude" (Byrne, 1996, p. 290). Two outstanding models, the Shavelson Model and the refined Marsh/ Shavelson model have marked such an endeavor to clarify the structure and nature of academic self-concept.

These differentiated self-concepts are not at the same level and of the same importance. Rather, they are hierarchically structured. As Shavelson et al hypothesized, self-perceptions of more specific competence, like English self-concept can impact the general academic competence, which in turn, influences the overall global self-concept (1976, p. 440). Some components play more important roles than others in shaping the global self-concept. Previous findings and modified Shavelson model suggest that it is reasonable to divide subject self-concept into more refined and specific self-concepts. Our assumption is supported by Lau et al's (1999) study which found the global English self-concept comprises and accounts for four skill-specific self-concepts, i.e., listening, speaking, reading and writing. Besides, research in psychology has pointed to two main sources of academic self-concept: academic achievements and significant others.

\section{Significant Others}

Early in the 1900s, the well-known self psychologist William James proposed three dimensions of the Me-self, namely, the material self, the social self and the spiritual self. For James, the social self refers to "people's evaluations of their acceptance by specific groups of other people" (Berndt \& Burgy, 1996, p. 172). This laid the foundation of the multidimensionality of self-concept in contemporary self psychology, and anticipated the importance of evaluations by significant others that clearly voiced by scholars like Cooley (1902) and Mead (1934). Roche and Marsh (2001) found in their research on university teachers' self-concept-self-conception of their own teaching effectiveness by using multitrait-multimethod analysis that feedback from significant others (students) influences teachers' self-concept.

From the definition, we can see that significant others play an important role in forming one's self-concept. What is more underscored is its role as a frame of reference. This is especially so with academic self-concept. Festinger (1954) argued for his social comparison theory that people use significant others in their environment as frames of reference in forming self-assessments. For example, for students, teachers and fellow students serve as the most important significant others in the formation of their self-conceptions. The classic model of "internal/ external frame of reference" proposed by Marsh (1986) goes one step further to demonstrate the role of a referential standard of significant others.

"Significant others" is also a part of the language learning process. For social constructivists, learning takes place within a certain social context through interactions with others (Donato \& McCormick, 1994). According to this, language learning in the classroom setting is primarily a process of interaction with language teachers and classmates. The popular CLT approach has this very view as its theoretical rationale.

\section{Inferred Self-concept}

Inferred self-concept is an alternative measurement of self-concept in response to the problem of socially desirable responding in self-reports. Studies find that right into adolescence, one's self is differentiated into multiple selves. Among them, some are true selves; some others are false selves. From a social psychologist's perspective, false selves will be presented in place of true selves to win others' acceptance or approval (Snyder, 1987). This distinction between true selves and false selves reminds us of the problem of validity in self-report used to study one's self-concept. This problem appeals to some more objective measurement of self-concept, for example, inferring self-concept from ratings by others, like teachers, observers or peers, comparing the results with self-ratings to see the discrepancies. Reasons for the discrepancies should "illuminate our interpretation of self-evaluations" (Harter, 1996, p. 28). This is also why we asked the English teachers to do the questionnaires separately in our study. The aim is to achieve objectivity of response.

\section{Methodology}

\section{A. Subjects}

Subjects were 20 second-year students from two classes in Foreign Language College of Inner Mongolia University for the Nationalities. The writer selected 5 top students and 5 low achievers from each class as subjects according to both their English scores from a most recent final Examination and the English teachers' ratings. There were 38-50 students in each class, with about 30 girls and 20 boys on average. The rest of the students in each class, together with their English teacher, were to evaluate the 10 subjects. These students who performed evaluation were taken as 
important others.

\section{B. Method}

The self-report questionnaire was adopted to measure the subjects' self-concept and the inferred self-concept.

The self-evaluation scale (42 items) used in the study is an academic self-concept instrument. Following the theory of self-concept, it is adapted from Investigation of Academic Status Quo of Middle School Students (Pan, 2003), which is substantially based on the Self Description Questionnaire II (SDQII)(Marsh, 1992) and consists of 76 items, 9 subscales (General self-concept, Physical Appearance, Mathematics, Chinese, English, Oral English, English Pronunciation, English Teacher Relations, General Status in School). Each subscale contains 8 items except those of Mathematics and English which contain 10 items. There are six response categories for each item: false, mostly false, more false than true, more true than false, mostly true, true. The total score ranges from 76 to 456 . To focus on English academic self-concept and English pronunciation, the present academic self-concept scale adopted the subscales of General/Global self-concept (8 items), English (10 items), oral English (8 items), English Pronunciation (8 items) and English Teacher Relations ( 8 items), thus contained 42 items altogether.

To examine whether self-evaluation and other-evaluation are consistent, we selected the four subscales of General self-concept, English, Oral English and English Pronunciation from the self-concept scale, and made an other-evaluation scale containing 34 items that was readable to teachers and students. Each item in the other-evaluation scale corresponds to that in the above academic self-concept scale. We change the person from "I" to "he/she", and modified some wording. The items were likewise randomized on the questionnaire for the students. The structure of this questionnaire is basically the same as the self-evaluation questionnaire except that in the instruction, the students were required to evaluate others according to their knowledge of them.

Analyses were conducted with SPSS (11.0).

\section{ANALYSIS AND DISCUSSION}

The correlation between self-evaluation and other-evaluation variables was generally significantly high. Table 1 provides a complete correlational matrix for all the correlations between the variables. Self-evaluation and other-evaluation were significantly correlated as expected, which was clearly shown by the correlation coefficients between total scores of self-evaluation and mean scores of other-evaluation $\left(r=0.756, p<0.01\right.$, see the $6^{\text {th }}$ column and the $2^{\text {nd }}$ row from the bottom of Table 1); between scores of self-evaluation and other-evaluation of general self-concept $\left(\mathrm{r}=0.625, \mathrm{p}<0.01\right.$, see the $1^{\text {st }}$ column and the $7^{\text {th }}$ row of Table 1$)$, English $\left(r=0.774, p<0.01\right.$, see the $2^{\text {nd }}$ column and the $8^{\text {th }}$ row of Table 1$)$, oral English $\left(r=0.739, p<0.01\right.$, see the $3^{\text {rd }}$ column and the $4^{\text {th }}$ row from the bottom of Table 1$)$, English pronunciation $\left(\mathrm{r}=0.770, \mathrm{p}<0.01\right.$, see the $4^{\text {th }}$ column and the $3^{\text {rd }}$ row from the bottom).

Since our focus in this study is English pronunciation and English self-concept, we singled out the two relevant subscales in the questionnaires for a detailed analysis. The correlations between self-evaluation of pronunciation, self-evaluation of English, other-evaluation of pronunciation, other-evaluation of English were statistically significant and moderately high. Among them, self-rating of English pronunciation is highly correlated with subjects' English self-concept (self-rating of English) $\left(r=0.882, p<0.01\right.$, see the $2^{\text {nd }}$ column and the $4^{\text {th }}$ row), indicating that English pronunciation self-concept does bear on foreign language learners' English self-concept. Besides, it was also correlated with other-evaluation of English pronunciation ( $\mathrm{r}=0.770, \mathrm{p}<0.01)$, other-evaluation of the subjects' English self-concept $\left(\mathrm{r}=0.729, \mathrm{p}<0.01\right.$, see the $4^{\text {th }}$ column and the $5^{\text {th }}$ row from the bottom of Table 1), and their spoken English ( $\mathrm{r}=0.750$, $\mathrm{p}<0.01$, see the $4^{\text {th }}$ column and the last row but three). Moreover, self-rating of English pronunciation was found to be significantly correlated with English achievement ( $r=0.736, p<0.01$, see the last row), and even self-concept of the relations with English teacher $\left(r=0.405, \mathrm{p}<0.01\right.$, see the $4^{\text {th }}$ column and the $5^{\text {th }}$ row), although the correlation coefficient was only moderated. What is worth mentioning is that the correlation between English pronunciation self-concept and general self-concept $(r=0.770)$ was the highest among all the correlations between general self-concept and the self-evaluation variables (see the $1^{\text {st }}$ column and the upper part of Table 1).

The correlations of other-evaluation of English pronunciation were strikingly high with the remainder of the other-evaluation variables-0.946 for other-rating of general self-concept (see the $7^{\text {th }}$ column and the $3^{\text {rd }}$ row from the bottom of Table 1), 0.964 for that of English (see the $8^{\text {th }}$ column and the $3^{\text {rd }}$ row from the bottom), 0.980 for the inferred oral English self-concept (the $9^{\text {th }}$ column and the $3^{\text {rd }}$ row form the bottom). Other-rating of English pronunciation was moderately linked with general self-concept $\left(\mathrm{r}=0.660\right.$, the $1^{\text {st }}$ column and the $3^{\text {rd }}$ row from the bottom), highly linked with self-rating of English ( $\mathrm{r}=0.760$, the second column and the $3^{\text {rd }}$ row from the bottom), the oral English ( $r=0.744$, the $3^{\text {rd }}$ column and the $3^{\text {rd }}$ row from the bottom).

Self-rating of English was highly correlated with all the other-evaluation variables-0.738 for general self-concept, 0.765 for oral English, 0.760 for pronunciation (see the $2^{\text {nd }}$ column and the lower part of Table 1). 
TABLE 1

CORRELATIONS AMONG SELF-EVALUATION AND OTHER-EVALUATION VARIABLES AND ENGLISH EXAM SCORE

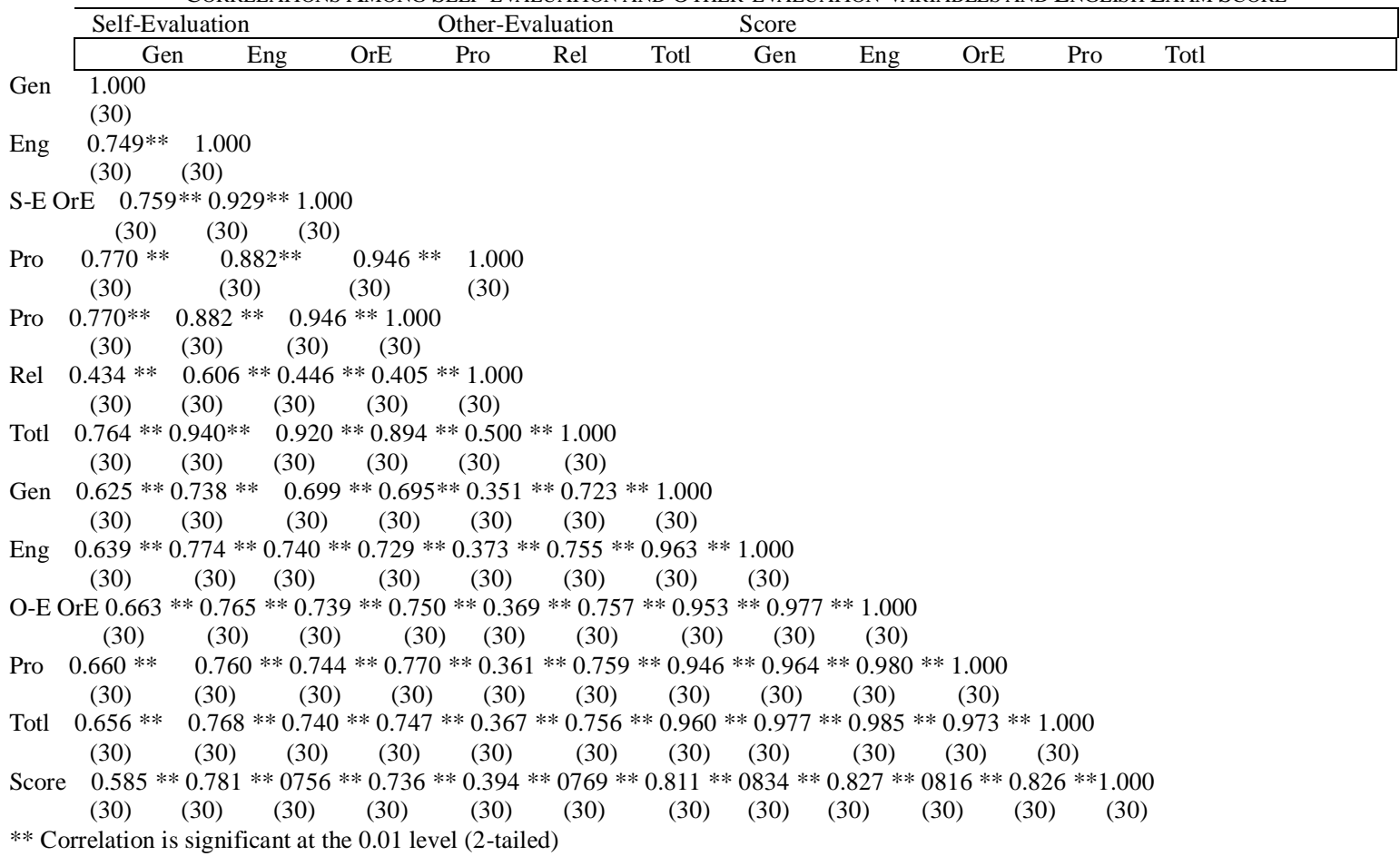

Note. S-E: self-evaluation; O-E: other-evaluation; Score: English exam scores in the last year's final examination; Gen: General self-concept; Eng: English; OrE: Oral English; Pro: English Pronunciation; Rel: English Teacher Relations; Totl: total score of self-evaluation or mean score of other-evaluation.

$\mathrm{N}=30$

Another noteworthy phenomenon is that correlations between self-rating of relations with English teacher and the rest of self-evaluation and other-evaluation variables were generally low, though significant ( $\mathrm{r}$ is around 0.3-0.4). Interestingly, the correlations between other-evaluation variables and English exams scores were much higher than between self-evaluation variables and English exam scores. Compare the figures in Table 2.

TABLE 2

COMPARING THE CORRELATIONS BETWEEN ENGLISH EXAM SCORES AND SELF-EVALUATION VARIABLES AND OTHER-EVALUATION VARIABLES

\begin{tabular}{|l|l|l|l|l|l|l|l|l|l|l|}
\hline & \multicolumn{1}{|l|}{ Other-Evaluation } \\
\hline SCORE & Gelf-Evaluation & Eng & OrE & Pro & Totl & Gen & Eng & OrE & Pro & Totl \\
\cline { 2 - 14 } & $0.585^{* *}$ & $0.781^{* *}$ & $0.756^{* *}$ & $0.736^{* *}$ & $0.769^{* *}$ & $0.811^{* *}$ & $0.843 * *$ & $0.827 * *$ & $0.816^{* *}$ & 0.826 \\
\hline
\end{tabular}

** Correlation is significant at the 0.01 level (2-tailed)

The questionnaire research generated the following results: English self-concept and the closely related inferred English self-concept are both significantly correlated with English achievement; English pronunciation self-concept is significantly correlated with all other-evaluation variables, English self-concept and English achievement, suggesting that pronunciation has a part to play in English language learning. Caution should be taken in interpreting the role of pronunciation because pronunciation self-concept does not equal the actual performance in pronunciation. Meanwhile, since the questionnaires, especially the other-evaluation scale used in this study, had not gone through repeated tests of their validity and reliability, a simple correlation between one variable and the other would not make us feel secure. To confirm the results from the questionnaire investigation we need to carry out interviews with subjects from the same classes.

\section{Conclusions}

The analysis of the questionnaire enables us to conclude that English self-concept is significantly highly correlated with English achievement. The correlations between inferred English self-concept (other-evaluation), English self-concept, and English achievement scores suggested the role of significant others in language learning. Pronunciation presumably has a role in the formation of English self-concept when we look at the high correlation among pronunciation self-concept and the rest of the self-evaluation and other-evaluation variables. This is also manifested in the interview data, which shows that pronunciation may be a mediating factor bearing on one's efforts, motivation, confidence and the whole self-concept in language learning. The additional finding that pronunciation is related to English achievement score affords further evidence for the role of pronunciation in English learning.

The present study is an examination of the role of pronunciation and significant others in English language learning 
in relation to the formation of English self-concept. Through two scales (one self-evaluation scale and an other-evaluation scale), the study demonstrated a strong link between pronunciation (self-concept), other-evaluation and English self-concept. The results show that pronunciation is closely related to other-evaluation, which in turn impacts on one's English self-concept. Another finding is the low but significant correlations of social self-concept (relations with the English teacher) with English self-concept, English pronunciation self-concept, other-evaluation etc.

\section{LIMITATIONS AND IMPLICATIONS FOR LANGUAGE TEACHING AND LEARNING}

The whole study was conducted only among the college students of two classes. This is an over-reliance on data from a single school, which calls into question of the generalizability of results to all college students. This might be determined by the research nature of the current study. Additional research could hopefully have larger samples from more sources to test the generalizability of the findings in this research.

The study did not address the issue of whether there are difference between teachers' responses and peers' responses. No careful examination of the students' pattern of responses to sets of items was carried out either, which must contain a lot of information about individual learning. Since there is no unitary success in foreign language learning, it is deemed of greater importance to probe into individual differences and factors contributing to them, rather than simply grouping learners according to certain attributes as the traditional psychometric research approach does in language learning (Williams \& Burden, 1997, p. 95). Further studies could "go beyond simply relating the two constructs: "academic self-concept and academic achievement" to detect the "key determinants" in different self-concepts across individuals (Hatti \& Marsh, 1996, p. 440).

\section{REFERENCES}

[1] Arnold, J. (1999). Affect in Language Learning. Cambridge: Cambridge University Press.

[2] Bandura, A. (1986). Social Foundations of Thought and Action. Englewood Cliffs, NJ: Prentice-Hall.

[3] Baumeister, R. F. (1990). Suicide as Escape from Self. Psychological Reviews, 97, 90-113.

[4] Berndt, T. J. \& Burgy, L. (1996). Social self-concept. In Bracken, B. (Ed.), Handbook of Self-Concept: Developmental, Social, and Clinical Considerations. New York: John Wiley \& Sons, Inc.

[5] Boivin, M. \& Begin, G. (1989). Peer status and self-perception among early elementary school children: The case of rejected children. Child Development, 60, 591-596.

[6] Bracken, B. A. (1996). Clinical applications of a context-dependent, multidimensional model of self-concept. In Bracken, B. (Ed.), Handbook of Self-Concept: Developmental, Social, and Clinical Considerations. New York: John Wiley \& Sons, Inc, 463-503.

[7] Brown, H. D. (2000). Principles of Language Learning and Teaching (4th ed.). New York: Addison Wesley Longman, Inc.

[8] Burns, R. B. (1979). The Self-concept in Theory, Measurement, Development and Behavior. London: Longman Group Limited.

[9] Byrne, B. M. (1990). Methodological approaches to the validation of academic self-concept: The construct and its measures. Applied Measurement in Education, 3, 185-207.

[10] Byrne, B. M. (1996). Measuring self-concept across the life span: Issues and instrumentation. Washington, D.C: American Psychological Association.

[11] Cooley, C. H. (1902). Human Nature and the Social Order. New York: Scribners.

[12] Donato, R. \& McCormick, D. (1994). A social cultural perspective on language learning strategies: The role of mediation. Modern Language Journal, 78, 453-464.

[13] Festinger, L. (1954). A theory of social comparison processes. Human Relations, 7, 117-140.

[14] Gardner, R. C. (1985). Social Psychology and Second Language Learning: The Role of Attitudes and Motivation. London: Edward Arnold.

[15] Gardner, R. C. \& MacIntyre, P. D. (1993). On the measurement of affective variables in second language learning. Language Learning, 43, 157-194.

[16] Harter, S. (1978). Effectance motivation reconsidered: Toward a developmental model. Human Development, $21,34-64$.

[17] Harter, S. (1996). Historical roots of contemporary issues involving self-concept. In Bracken, B (Ed.), Handbook of Self-Concept: Developmental, Social, and Clinical Considerations. New York: John Wiley \& Sons, Inc, 1-37.

[18] Hattie, J. \& Marsh, H. W. (1996). Future directions in self-concept research. In Bracken, B. (Ed.), Handbook of Self-Concept: Developmental, Social, and Clinical Considerations. New York: John Wiley \& Sons, Inc, 421-462.

[19] Keither, L.K. \& Bracken, B. (1996). Self-concept instrumentation: A historical and evaluative review. In Bracken, B (Ed.), Handbook of Self-Concept: Developmental, Social, and Clinical Considerations. New York: John Wiley \& Sons, Inc, 91-170.

[20] Krashen, S. D. (1985). The Input Hypothesis: Issues and Implications. New York: Longman.

[21] Lau, I. C. et al. (1999). Toward a hierarchical, multidimensional English self-concept. Journal of Educational Psychology, 91(4), 747-755.

[22] Marsh, H. W. \& Shavelson, R. J. (1985). Self-concept: Its multifaceted, hierarchical structure. Educational Psychologist, 20, $107-125$.

[23] Marsh, H. (1986).Verbal and math self-concepts: An internal/external frame of reference model. American Education Research Journal, 23, 129-149.

[24] Marsh, H. (1992). Self Description Questionnaire (SDQ) I: A theoretical and empirical basis for the measurement of multiple dimensions of preadolescent self-concept: A test manual and research monograph. Macarthur, NSW Australia: Faculty of Education, University of Western Sydney.

[25] Marsh, H. \& Byrne, B. M. (1993). Do we see ourselves as others infer: A comparison of self-other agreement on multiple dimensions of self-concept from two continents. Australian Journal of Psychology, 45, 49-58. 
[26] Marsh, H. \& Hattie, J. (1996). Theoretical perspectives on the structure of self-concept. In Bracken, B. (Ed.), Handbook of Self-Concept: Developmental, Social, and Clinical Considerations. New York: John Wiley \& Sons, Inc, 38-90.

[27] Mead, G. H. (1934). Mind, Self, and Society. Chicago: University of Chicago Press.

[28] Pan, W. (2003). English Pronunciation Self-concept: Its Effects on Chinese-speaking EFL Learners. (MA thesis). Guangdong University of Foreign Studies, Guangdong.

[29] Roche, L.A. \& Marsh, H. W. (2001).Teaching self-concept in higher education: Reflecting on multiple dimensions of teaching effectiveness. In N. Hativa \&P. Goodyear (Eds.), Teachers' Thinking, Beliefs and Knowledge in Higher Education. Dordrecht, The Netherlands: Kluwer Academic Publishers, 179-218.

[30] Schumann, J. H. (1994). Emotion and cognition in second language acquisition. Studies in Second Language Acquisition, 16, 231-242

[31] Schumann, J. H. (1997). The Neurobiology of Affect in Language. Boston: Blackwell.

[32] Seliger, H. \& Shohamy, E. (1989). Second Language Research Methods. New York: Oxford University Press.

[33] Shavelson, R. J., Hubner, J. J. \& Stanton, G. C. (1976). Self-concept: Validation of construct interpretations. Review of Educational Research, 46, 407-441.

[34] Shavelson, R. J. \& Bolus, R. (1982). Self-concept: The interplay of theory and methods. Journal of Educational Psychology, 74, 3-17.

[35] Snyder, M. (1987). Public appearance/Private realities: The psychology of self-monitoring. New York: W.H. Freeman.

[36] Stevick, E. W. (1976). Memory, Meaning \& Method. Rowley, Mass: Newbury House Publisher.

[37] Stevick, E. W. (1980). Teaching Language: A Way and Ways. Rowley, Mass: Newbury House Publisher.

[38] Stevick, E. W. (1986). Images and Options in the Language Classroom. Cambridge: Cambridge University Press.

[39] Stevick, E. W. (1990). Humanism in Language Teaching. Oxford: Oxford University Press.

[40] Stevick, E. W. (1998). Working with Teaching Methods: What's at Stake? Boston: Heinle \& Heinle.

[41] Strein, W. (1993). Advances in research on academic self-concept: Implications for school psychology. School Psychology Review, 22, 273-284.

[42] Wang, Chuming. (2001). The two major factors influencing L2 learning and their effect on L2 teaching. Foreign Language, 6 , $8-12$.

[43] Williams, M. \& Burden, R. L. (2000). Psychology for Language Teachers: A Social Constructivist Approach. Beijing: Foreign Language Teaching and Research Press.

[44] Williams, M. \& Burden, R. L. (1999). Students' developing conceptions of themselves as language learners. Modern Language Journal, 83, 193-201.

Meihua Wang was born in Hinggan League, Inner-Mongolia Autonomous Region, China in 1977.She received her M.A. degree in education from Inner Mongolia Normal University, China in 2008.

She is currently a lecturer in the School of Foreign Languages, Inner Mongolia University for the Nationalities, Tongliao, Inner-Mongolia Autonomous Region, China. Her research interests include Applied Linguistics and English-Mongolian Comparative Teaching.

Ms. Wang is awarded outstanding young teachers in innovation by Inner Mongolia University for the Nationalities. 